Journal of Management and Economic
Studies
$\begin{gathered}\text { 2019, 1(3): } 18-34 \text { DOI: } 10.26677 / T R 1010.2019 .94 \\ \text { Journal Homepage: } \text { https://www.jomaes.org }\end{gathered}$

\title{
Investigation on Conformance of Catering and Food Safety Practices at The National Youth Service in Kenya
}

\author{
Gitu Onesmus Ndaramu \\ Kenya Education Management Institute. Contact Email: ndaramujunior@gmail.com
}

\section{Richard O. B. Makopondo}

Hospitality Department, School of Hospitality and Tourism Studies, Technical University of Kenya. Contact Email: rmakopondo@tukenya.ac.ke

Ann Kariuki

School of Business, Karatina University. Email: w.kariuki@hotmailcom

\begin{abstract}
Purpose was to determine the influence of food handling practises on food safety at the National Youth Catering Units in Gilgil in Kenya. Descriptive survey research design comprising of mixed research methodology were adopted. Target population consisted of 121 employees in the catering department. Census method was used since the population was low. Data was collected using structured questionnaire, observation checklist and interview guide and then analyzed using descriptive and inferential statistics. Data was analyzed using Statistical Package for Social Sciences computer software and presented into percentage tables and graphs. Inferential statistics included regression analysis, correlation analysis and analysis of variance. Food safety policies and procedures provided detailed guidance for the staff though the practices were less followed. Supplies tools and materials were not readily available in adequate quantities to perform safe food handling practices. Equipment items needed to prepare food safely need to add more. Management should encourage partnership and collaboration between in order to enhance safe food production. Staff should use gloves while handling food production and also detergent water when cleaning vegetables and fruits. Management should also increase the supplies of tools and materials in adequate quantities so as to perform safe food handling practices. There is need to practice and encourage the culture of safe food preparation in the catering units. Food safety practices should be made to be part of the annual work performance evaluation process.
\end{abstract}

Keywords: Food production, Food handling services, Food safety, Catering services, Hospitality industry, Kenya 


\section{Introduction and Background Information}

Due to the changes over the years in mode of food production, delivery and storage, concerns have been raised on safety of consumed foods products and food-borne diseases (Yiannas, 2008). Aagaard, 2016 reported that in earlier years food was simply done with little processing, but today the food system has evolved into an increasingly complex network interdependent on many businesses, sectors, and individuals. Wilcock et al., (2004) reported that each year, 1 in 6 Americans gets sick by consuming contaminated foods or beverages. In Kenya, where food business is an order of the day with different stages of production, processing and distribution in the entire value chain adherence to satisfy relevant hygiene and regulations to maintain/control and enhance safety before and upon consumption is highly necessary. Application of Hazard Analysis and Critical Control Point (Hazard Analysis and Critical Control Point, HACCP) principle in food production and service areas is a requirement especially in global trade (Walker, et al., 2003). Successful implementation of the procedures based on the HACCP principles requires the full cooperation and commitment of food handlers' and employees should undergo training. According to Fone (2013), the specific practices are not endeared, thus the reason for there being so much experiences of food contaminations both internationally and locally.

Food-borne illness (sometimes mislabelled "food-borne disease", "food-borne infection", or "food poisoning") is a common, costly and yet a preventable public health problem caused through contamination by different disease-causing microbes (pathogens) and poisonous chemicals, or other harmful substances. Other diseases are poisoning, caused by harmful toxins or chemicals that have contaminated the food, for example, poisonous mushrooms. These different diseases have many different symptoms, so there is no one "syndrome" that is foodborne illness. However, the microbe or toxin enters the body through the gastrointestinal tract, and often nausea, vomiting, abdominal cramps and diarrhoea are common symptoms in many food-borne diseases. Food-borne diseases and surveillance systems are a major issue in African countries; food is a major factor in transmission of diarrheal diseases. Most African countries lack or have weak surveillance system thus investigation of food-borne disease causative factors and magnitude of exposure are inadequate (WHO, 2012. According to Wagacha and Muthomi(2008) the poor documentation can be attributed to underreporting of food-borne illness.

In developed countries there are intricate standards for food preparation, whereas in lesser developed countries the main issue is simply the availability of adequate safe water, which is usually a critical item (WHO, 2010). ISO 22000 which is a standard developed by the International Organization for Standardization dealing with food safety, specifies the requirements for a food safety management system that involves interactive communication, system management and prerequisite programs. HACCP principles if well put into practice by all food handlers worldwide will improve food safety (American National Standards Institute, 2016). Centre for Disease Control (CDC) estimates that each year roughly 48 million people get sick from a food-borne illness, 128,000 are hospitalized, and 3,000 die. According to CDC (2015), investigating the food processing chain could help stop potential outbreaks and illnesses.

Outbreak investigations are also opportunities for different authorities and professionals to work together as a team. They may reveal points at which the public health systems that detect and respond to outbreaks can be improved. Outbreak investigations and additional research should result in better industry practices, better regulations and enforcement by the regulatory agencies, and better consumer understanding, all of which should reduce the number of foodborne illnesses that occur. Despite this probably good measure having been put in place in 
developed countries, the challenge of food-borne illness is still experienced. For instance, due to the issue of food safety, Weiland (2012) reports that Australia has developed rules and regulations to enhance food safety standards. Food Standards Australia requires all food businesses to implement food safety systems, (Weiland, 2012). Europe has also come up with rules and regulations to be followed by all food handlers food standards agency.

In Kenya, the existing legal framework for food safety and quality research have not been effective with the results some food products been of sub-standard in the Kenyan market (Olielo \& Rombo, 2009). Cases of food poisoning have been reported in institutions of learning, and all these could be attributed to how hospitality departments in learning institutions handle the issue of food and its safety upon consumption. Putting into consideration that, hygiene practices culture is a pattern of shared basic assumptions that a group learn, taught to new members as the correct way to perceive, think, and feel. While quality culture is prevailing attitudes and behaviors related to quality that is taught, directly and indirectly, to new employees (Taylor, 2011). Food safety can probably be influenced by institutional culture. Accordingly, retail and foodservice establishments, as well as food producers at all levels of the food production chain, have a growing responsibility to ensure that proper food safety and sanitation practices are followed, thereby safeguarding the health of their customers (Yiannas, 2008). The number of incidences or occurrences with regard to food safety mentioned or reported in public institutions suggests the need to conduct research. It is mandatory for the service recruits to get food from the messes, which makes food hygiene to be all more critical. Bearing in mind that incidences of food borne illnesses have been reported in many public institutions in the country lately, the study looked in-depth into the practices and culture that may possibly influence safe food handling and catering services in Kenya. Food poisoning is a challenge and measures need to be taken and continually improved to avert this problem.

\section{Statement of the Problem}

Food poisoning and contamination has become a major issue in our public institutions, with so many incidences being reported and some still in the hidden by food consumers. Hygiene practices covers proper acquisition and storage of food items, maintenance of clean environment during food preparation and serving, and assurance that all equipment and serving dishes are clean/ free from pathogens and further contaminants (Lee, Chik, Baka, Saari, \& Mahyudin, 2012). Food safety plays a significant role in the economic and health development of Nations by safeguarding the nation's health, enhancing tourism, hospitality and international trade, the production, distribution and consumption of safe food (Tansey \& Worsley, 2014). Numerous foods safety's scares and emergencies have occurred over the past years in learning institutions food supply and production chain. Failure to protect the safety of food leads to a decline in consumer confidence in the safety of many food products and threatens the health and wellbeing of any given individual. This creates the need to investigate how institutional culture influences food safety in Kenya. In addition, strategies need to be developed to improve and cub food safety throughout the food system in any learning or training institution especially those serving a huge number of individuals since any food infection could affect thousands of individuals. Furthermore, gaps exist in terms of unreported illnesses and on the extent to which HACCP principles are adhered to in these institutions. In particular the study tried to find how catering practices influences food safety in a large public organization.

\section{Purpose and Objectives of the Study}

Purpose was to investigate conformance of institutions to the catering and food safety practices at the National Youth Service Catering Units in Kenya. Specific objectives were to: 
i) Determine the effect of standard operation procedures and catering policies on food safety at the National Youth Service Catering Units.

ii) Examine the influence of food-handling practices on food safety at the National Youth Service Catering Units.

iii) Assess the implementation of hazard analysis and critical control points principles and their effect on food safety at the National Youth Service Catering Units.

\section{Hypotheses}

i) Catering policies do not have a statistically significant effect on food safety at the institution.

ii) Food handling practices do not have a statistically significant influence on food safety at the institution.

iii) Implementation of hazard analysis and critical control points principles do not have statistically significant effect on the food safety at the institution.

\section{Literature Review}

\section{Food safety}

Food safety has been defined as conditions and measures that are necessary during production, processing, storage, distribution and preparation of food to ensure that it is safe, sound, and wholesome and fit for human consumption (WHO, 2012). Yiannas(2008) asserts that food handlers neglecting the basic rule of food preparation such as mishandling and taking for granted hygiene practice contributed to the outbreaks of food poisoning. According to Tansey and Worsley(2014) food safety is a scientific discipline describing handling, preparation, storage and presentation of food in ways that prevent food borne illness. This includes a number of routines that should be followed to avoid potentially severe health hazards. The tracks within this line of thought are safety between industry and the market and then between the market and the consumer (Shravani, 2012).

Considering industry to market practices, food safety considerations include the origins of food including the practices relating to food labeling, food hygiene, food additives and pesticide residues, as well as policies on biotechnology, food guidelines for the management of governmental import and export inspection and certification systems for foods. Considering market to consumer practices, the usual thought is that food ought to be safe in the market and the concern is safe delivery and preparation of the food for the consumer (Yiannas, 2012). Aagaard (2016) revealed that there were deficiencies in attitudes, knowledge and practices in safe food handling among food handlers. Therefore the core knowledge of food handlers may come from the root of the problem. Graduates who trained on food hygiene and sanitation play a major role in determining the level of awareness among food handlers in the industry. Food can transmit diseases from person to person as well as serve as a growth medium for bacteria that can cause food poisoning. In developed countries there are intricate standards for food preparation, whereas in less developed countries the main issue is simply the availability of adequate safe water, which is usually a critical item (WHO, 2012).

Contamination of produce with harmful micro-organisms can occur at all stages of production, processing, transportation, storage, preparation, and service. Al Yousuf, Taylor and Taylor(2015) assert that to prevent food borne illness, fresh produce needs to be handled with care at each step from farm to table. Auslan (2013) cautions practitioners to work with lot of 
caution while purchasing and receiving food commodities by use of purchasing specifications. These specifications include food safety requirements, such as maintaining produce at the proper temperature, maintaining clean and pest-free storage areas and delivery vehicles and complying with food safety laws and regulations. More so, to ensure suppliers are getting produce from licensed, reputable sources and check storage and handling practices of vendors are adhered to. There should also be established procedures for inspecting, accepting or rejecting incoming deliveries. Cramer (2013) argues that procedures should include checking the condition of fresh produce and the transportation vehicles to make sure specifications are met. Thorough washing should be practiced for all fresh products and more so the equipment and tools. Wash produce before serving or cutting and this should be done on running water. Chemical disinfectants, used according to the manufacturer's label instructions for recommended concentration and contact time (Tansey \& Worsley, 2014). It should be noted that fresh products should not be soaked or stored in standing water, never rewash packaged produce labelled "ready-to-eat," "washed," or "triple washed". Never the less, wash thoroughly with hot soapy water all equipment, utensils and food contact surfaces that come into contact with cut produce(Rinse, sanitize, and air-dry before use) (Cramer, 2013).

\section{Food Catering Polices}

In a broader perspective, food safety action plan draws the line for minimum expected standards and the overall objectives of food safety system of a country (Nguz, 2007). Yiannas(2009) observed that systems and guidelines should be put in place to enhance food safety by all food handlers. It identifies the approach the nation uses and the goals/targets the system aims to achieve. In Kenya, the nationwide food quality and safety systems are legally controlled by various government agencies under different ministries (WHO, 2010). Food safety regulation agencies work under the Ministries of Trade, Industrialization, Public Health and Sanitation, Livestock, Fisheries and Agriculture. Such agencies include the Kenya Bureau of Standards (KEBS), Kenya Agricultural Research Institute (KARI), Department of Public Health (DPH), and Kenya Plant Health Inspectorate Services (KEPHIS) among others (Nguz, 2007). These agencies aim at disseminating information on the code of hygiene necessary to all food handlers. This is followed by supervision and implementation of the mentioned practices. Food safety is dependent upon the significant roles played by food handlers along the food service system. Food handlers may introduce pathogenic microbes to the food during the process of preparation, distribution and serving (Yiannas, Food Safety Culture, 2009). This is through inoculation of the food with infected excreta, pus, exhalations and other body discharges.

According to Huuhtanen and Laukkanen (2006), all food handlers should understand and internalize that Personal hygiene begins at home, with the essential elements for good hygiene being a clean body, clean hair and clean clothing. Hair in food can be a source of both microbiological and physical contamination. Hairnets and beard covers should be worn to assure food product integrity. Moreover, Hennessey (2012) observed that long-sleeved smocks should be worn to cover arm hair. In addition, clean uniforms, aprons and other outer garments that are put on after the employee gets to work can help minimize food contamination. While working, clothing should be kept reasonably clean and in good repair (Booty, 2009). According to Booty, removal of smocks, lab coats or aprons should take place when leaving the work area to go to the employee break room, restroom or exiting the building. Rodriguez, Valero, PosadaIzquierdo, Carrasco, and Zurera (2011) assert that the only jewelry allowed in a food plant is a plain wedding band and/or one small post earring in each ear and no other jewelry is to be worn because it may fall into the product, it can present a safety hazard and it cannot be adequately sanitized against bacterial transmission. It should be removed prior to entering the processing facility. 
Food safety does not happen by accident. To prepare safe food, you must follow certain steps and procedures throughout the entire food preparation process. You have to think, and you have to pay attention to how you prepare food to make sure it is safe. You do this by developing a food safety plan. A good food safety plan will make sure that anything that might make someone sick is under control (Foskett \& Ceserani, 2007). Clear structure, rules and procedures on hygiene rules of workers on dress code and covering, health requirements of workers and routines, stipulated procedures or manual on food storage, refrigeration, leftover foods, cleanliness and serving temperatures should be put in place (WHO, 2010). Kenya is deficient of a distinct and published policy for food safety. Separate laws have been put in place to safeguard the consumers. The primary food safety laws are the Food, Drugs and Chemical Substances Act, Chapter 254; The Public Health Act, Chapter 242 and The Meat Control Act, Cap 356 (GOK, 2007). The law mandates the minister for Public Health and Sanitation to orchestrate all the activities by the various agencies concerned in food safety management through the department of public health (DPH).

\section{Food Handling Practices}

Good food hygiene is essential to all food handlers involved in food handling procedure. It is very important for all catering brigade to understand good food hygiene is for it helps one to reduce the risk of food poisoning among food consumers and protect business's reputation (Schlosser, 2012). According to Chesworth (2012), good food hygiene is about controlling harmful bacteria, which can cause illness and can occur in four main things to remember for good hygiene, cross-contamination, cleaning, chilling and cooking. At each step in the flow of food through a food service establishment, there are general food safety procedures that should be followed. This should help reduce the risk of contamination and mishandling that could consequently lead to food-borne illness outbreaks. These are; procuring, storage, preparation, actual production or cooking and food presentation (Al Busaidi \& Jukes, 2015).

Additionally, no employee who is affected with, has been exposed to, or is a carrier of a communicable disease, the flu or a respiratory problem, or any other potential source of microbiological contamination shall work in any area where there is a reasonable possibility that food or food ingredients can be contaminated (Chesworth, 2012). In addition, it is ethical and of great consideration for food production plant or company to have a working policy which should be established requiring that employees report any active case of illness to supervisors before beginning work (Cramer, 2013). Consequently, if an employee has been diagnosed with a food-borne illness, they should be excluded from the establishment, and contact the local health department (Chesworth, 2012; Cramer, 2013). Employees must wash and sanitize their hands thoroughly in a hand-washing facility before starting work, especially if the employee has direct contact with food. The hands should also be washed after each absence from the work area, after visiting the restrooms, after eating, drinking, smoking, chewing gum, chewing tobacco, coughing, using a handkerchief or tissue and any other times when hands have become soiled or contaminated (Todd, Michaels, Greig, Smith, Holah \& Bartleson, 2010).

\section{Hazard Analysis Critical Control Points Principles}

Hazard analysis and critical control point is a management system in which food safety is addressed through the analysis and control of biological, chemical, and physical hazards from raw material production, procurement and handling, to manufacturing, distribution and consumption of the finished product. HACCP is a system that helps food business operators look at how they handle food and introduces procedures to make sure the food produced is safe 
to eat (CDC, 2012). Manley (2011) says that there should be development of a range of food safety management packs for different sectors of the food industry to help food production operators manage their food safety management procedures. The HACCP system can be used at all stages of a food chain, from production and preparation processes including purchasing, preparation, cooking, packaging and presentation (Troy\& Kerry 2010). However, food safety programs should be designed to help food handlers identify and manage hazards to food safety (CDC, 2012). All food production and processing food handlers must develop own and implement a documented food safety program (FSP) for this will help curb food contamination issues (Chesworth, 2012). According to Sun and Ockerman (2005), food safety programs that identify potential hazards that may occur in all food handling operations carried out in the business should identify where these hazards can be controlled; monitor these control methods, provide corrective actions when a hazard is found to be not under control, establish, document and verify detailed pre-requisite programs; and regularly reviewed for adequacy. This would be the most appropriate one to any given food production sector.

\section{Research Methodology}

\section{Research Design and Sampling Techniques}

Mixed research methodologies of qualitative and quantitative research approaches were used. Qualitative data consists of open-ended structured questionnaire information, interview checklist and observations. Quantitative data was collected through self-administered questionnaire from the key respondents. In Kenya, the National Youth Service is the pride and backbone of youth training under the Ministry of Public Service, Youth and Gender Affairs with 21 camps in the across the country. The whole population of 121employees in the catering department was considered for the research. Structured questionnaire and interview guide were the main instruments of data and information collection. Quantitative data from the questionnaires were tabulated, coded and processed by use of the statistical package for social sciences (SPSS), and organized into themes and subthemes of the study. Analysis of quantitative data was accompanied with tabulations, graphs and percentages.

\section{Discussion of Findings}

\section{Food Catering Policies and Food Safety}

First objective determined the effect of standard operation procedures and catering policies on food safety at the National Youth Service Catering Units. Findings established that majority agreed that food safety policies and procedures provided detailed guidance for practices while most didn't believe that these regulations are nothing more than a cover-up in case there is a lawsuit and thus do not regard them as mere formality. In addition, to majority did not think that all the necessary information for handling food safely is readily available while to majority did not think that the management provided adequate training to improve employees' food safety practices quality. In addition, to majority never thought that the management provided adequate training to improve employees' food safety practices while majority did not think the managers' actions showed that providing safe food to customers is a top priority though this was almost equal to those who had a different opinion. This implies a divided response to the question whether managers at the institution acted to show that providing safe food to customers is a top priority. 
Table 1: Food Catering Policies and Food Safety

\begin{tabular}{|c|c|c|c|c|c|}
\hline \multirow[t]{2}{*}{ Training and Skills } & \multicolumn{5}{|c|}{ Respondents Number \& Percent } \\
\hline & $\begin{array}{c}\text { Strongly } \\
\text { Agree }\end{array}$ & Agree & $\begin{array}{l}\text { Not } \\
\text { Sure }\end{array}$ & $\begin{array}{c}\text { Disagre } \\
\mathrm{e}\end{array}$ & $\begin{array}{l}\text { Strongly } \\
\text { Disagree }\end{array}$ \\
\hline $\begin{array}{l}\text { Are there written food safety } \\
\text { policies and procedure in your } \\
\text { work area }\end{array}$ & $\begin{array}{c}20 \\
(21.5 \%)\end{array}$ & $\begin{array}{c}13 \\
(14 \%)\end{array}$ & $\begin{array}{c}55 \\
(59.1 \%)\end{array}$ & $\begin{array}{c}14 \\
(4.3 \%)\end{array}$ & $\begin{array}{c}1 \\
(1.1 \%)\end{array}$ \\
\hline $\begin{array}{l}\text { Management provides adequate } \\
\text { and timely information about } \\
\text { current food safety rules and } \\
\text { regulations }\end{array}$ & $\begin{array}{c}10 \\
(10.8 \%)\end{array}$ & $\begin{array}{c}38 \\
(20.9 \%)\end{array}$ & $\begin{array}{l}31 \\
(33.3 \%)\end{array}$ & $\begin{array}{c}11 \\
(11.8 \%)\end{array}$ & $\begin{array}{c}3 \\
(3.2 \%)\end{array}$ \\
\hline $\begin{array}{l}\text { Food safety policies and } \\
\text { procedures give detailed } \\
\text { guidance for practices }\end{array}$ & $\begin{array}{c}10 \\
(10.8 \%)\end{array}$ & $\begin{array}{c}37 \\
(39.8 \%)\end{array}$ & $\begin{array}{l}34 \\
(36.6 \%)\end{array}$ & $\begin{array}{c}11 \\
(11.8 \%)\end{array}$ & $\begin{array}{c}1( \\
1.1 \%)\end{array}$ \\
\hline $\begin{array}{l}\text { Views that written food safety } \\
\text { policies and procedures are } \\
\text { nothing more than a cover-up } \\
\text { against potential lawsuit }\end{array}$ & $\begin{array}{c}8 \\
(8.6 \%)\end{array}$ & $\begin{array}{c}17 \\
(18.3 \%)\end{array}$ & $\begin{array}{c}25 \\
(26.9 \%)\end{array}$ & $\begin{array}{c}12 \\
(12.9 \%)\end{array}$ & $\begin{array}{c}31 \\
(33.3 \%)\end{array}$ \\
\hline $\begin{array}{l}\text { Availability of all necessary } \\
\text { information for handling food } \\
\text { safely to respondents }\end{array}$ & $\begin{array}{c}17 \\
(18.3 \%)\end{array}$ & $\begin{array}{c}7 \\
(7.5 \%)\end{array}$ & $\begin{array}{c}31 \\
(33.3 \%)\end{array}$ & $\begin{array}{c}30 \\
(32.3 \%)\end{array}$ & $\begin{array}{c}17 \\
(18.3 \%)\end{array}$ \\
\hline $\begin{array}{l}\text { Management provides adequate } \\
\text { training to improve employees' } \\
\text { food safety practices }\end{array}$ & $\begin{array}{c}10 \\
(10.8 \%)\end{array}$ & $\begin{array}{c}29 \\
(31.2 \%)\end{array}$ & $\begin{array}{c}33 \\
(35.5 \%)\end{array}$ & $\begin{array}{c}16 \\
(17.2 \%)\end{array}$ & $\begin{array}{c}5 \\
(5.4 \%)\end{array}$ \\
\hline $\begin{array}{l}\text { Management will not take even a } \\
\text { small risk when it comes to food } \\
\text { safety }\end{array}$ & $\begin{array}{c}22 \\
(23.7 \%)\end{array}$ & $\begin{array}{c}20 \\
(21.5 \%)\end{array}$ & $\begin{array}{c}25 \\
(26.9 \%)\end{array}$ & $\begin{array}{c}11 \\
(11.8 \%)\end{array}$ & $\begin{array}{c}15 \\
(16.1 \%)\end{array}$ \\
\hline $\begin{array}{l}\text { Managers' actions show that } \\
\text { providing safe food to customers } \\
\text { is a top priority }\end{array}$ & $\begin{array}{c}32 \\
(34.4 \%)\end{array}$ & $\begin{array}{c}29 \\
(31.2 \%)\end{array}$ & $\begin{array}{c}16 \\
(17.2 \%)\end{array}$ & $\begin{array}{c}6 \\
(6.5 \%)\end{array}$ & $\begin{array}{c}10 \\
(10.8 \%)\end{array}$ \\
\hline $\begin{array}{l}\text { Managers actively ensure } \\
\text { practicing of safe food handling }\end{array}$ & $\begin{array}{c}20 \\
(21.2 \%)\end{array}$ & $\begin{array}{c}42 \\
(45.2)\end{array}$ & $\begin{array}{c}22 \\
(23.7 \%)\end{array}$ & $\begin{array}{c}3 \\
(3.2 \%)\end{array}$ & $\begin{array}{c}6 \\
(6.5 \%)\end{array}$ \\
\hline $\begin{array}{l}\text { Respondents follow and practice } \\
\text { food safety rules because they } \\
\text { know they are important }\end{array}$ & $\begin{array}{c}11 \\
(11.8 \%)\end{array}$ & $\begin{array}{c}16 \\
(17.2 \%)\end{array}$ & $\begin{array}{c}42 \\
(45.2 \%)\end{array}$ & $\begin{array}{c}16 \\
(17.2 \%)\end{array}$ & $\begin{array}{c}8 \\
(8.6 \%)\end{array}$ \\
\hline $\begin{array}{l}\text { New employees and experienced } \\
\text { employees work together to } \\
\text { ensure food safety practices }\end{array}$ & $\begin{array}{c}9 \\
(9.7 \%)\end{array}$ & $\begin{array}{c}43 \\
(46.2 \%)\end{array}$ & $\begin{array}{c}32 \\
(34.4 \%)\end{array}$ & $\begin{array}{c}5 \\
(5.4 \%)\end{array}$ & $\begin{array}{c}2 \\
(4.3 \%)\end{array}$ \\
\hline $\begin{array}{l}\text { Food safety training/education } \\
\text { provided by management } \\
\text { improves practices }\end{array}$ & $\begin{array}{c}21 \\
(22.6 \%)\end{array}$ & $\begin{array}{c}25 \\
(26.9 \%)\end{array}$ & $\begin{array}{c}36 \\
(38.7 \%)\end{array}$ & $\begin{array}{c}7 \\
(7.5 \%)\end{array}$ & $\begin{array}{c}4 \\
(4.3 \%)\end{array}$ \\
\hline $\begin{array}{l}\text { Cooperation among departments } \\
\text { to ensure safe food preparation }\end{array}$ & $\begin{array}{c}16 \\
(17.2 \%)\end{array}$ & $\begin{array}{c}35 \\
(37.6 \%)\end{array}$ & $\begin{array}{c}32 \\
(34.4 \%)\end{array}$ & $\begin{array}{c}3 \\
(3.2 \%)\end{array}$ & $\begin{array}{c}7 \\
(7.5 \%)\end{array}$ \\
\hline $\begin{array}{l}\text { Food safety policies and } \\
\text { procedures help to ensure } \\
\text { adherence to safe food handling } \\
\text { practices }\end{array}$ & $\begin{array}{c}32 \\
(34.4 \%)\end{array}$ & $\begin{array}{c}29 \\
(31.2 \%)\end{array}$ & $\begin{array}{c}21 \\
(22.6 \%)\end{array}$ & $\begin{array}{c}6 \\
(6.5 \%)\end{array}$ & $\begin{array}{c}5 \\
(5.4 \%)\end{array}$ \\
\hline
\end{tabular}

Additionally, six key informants commented that the policies help in ensuring that workplace cleanness is maintained. Policies such as SOPs aim at ensuring that food service providers comply with 
food safety legislation, and ensure that people who use the services, staff and visitors are not at risk of food poisoning. Food should be purchased, stored prepared cooked and served in such a way and under such conditions as to prevent contamination, thereby controlling the risk of food poisoning. The institution ensures that food handlers meet food safety standards, which is a policy requirement. Findings indicated that food catering policies can be explained by $38.9 \%$ of variance in food safety. Food catering policies and availability of written food safety policies and procedures have a great effect on food safety. The null hypothesis that states that catering policies do not have a statistically significant effect on food safety at the institution was rejected.

Evidence suggests that the management falls short of providing adequate and timely information about current food safety rules and regulations. According to University of Mississippi (2017) food safety standard operating procedures (SOPs) are written practices and procedures that are critical to producing safe food. It is essential to have these SOPs in place and to train food-service employees to use them. In addition, policies should ensure "Due Diligence" in respect of food safety, ensuring all food handlers are appropriately trained and all areas of food safety are risk assessed as well as ensuring compliance (Jabbar \& Grace, 2012). There is inadequate adequate training of personnel meant to improve food policies and food safety. This implies the catering department has a shortfall in providing adequate training to the staff to improve employees' food safety practices.

According to FAO (2016)states that though consumers, governments and other stakeholders play an important role in ensuring both food safety and quality, in free-market societies the ultimate responsibility for investing the physical and managerial resources necessary for implementing appropriate controls correspond with food industry that continuously oversees manufacture and processing of foods. The management in a place offering food service should therefore continuously offer leadership that ensures highest level of food safety. To some extent the management of the catering department do not take risks when it comes to food safety although there is room for improvement and thus the managers should be more cautious. It suggests that the managers should be more proactive in providing food safety initiatives at the catering units. New employees and experienced employees work together to ensure food safety practices are in place, hence there is teamwork between new and old employees as a measure of enhancing food safety. Food safety training/education provided by management is useful in improving the practices and the profession. There is good cooperation among departments in order to ensure that consumers receive prepared food safely. It further suggests that there is need for the management to encourage cooperation between the different departments in order to enhance safe food practices.

\section{Food Handling Practices}

Second objective examined the influence of food-handling practices on food safety at the National Youth Service Catering Units. In the multiple response question, majority of the respondents disagreed that they use food gloves when preparing food items. This implies that majority of the respondents do not use food gloves when preparing food items, hence the staff should be sensitized on the need to adopt usage of gloves as a way of boosting safe food handling at the institution. Detergent and water are used when cleaning the vegetables and food commodities are normally frozen where the refrigerator is available for storage of perishable foods. There were adequate supplies tools and materials such as gloves and thermometers which are readily available to perform safe food handling practices. This implies that supplies tools and materials are not readily available in adequate quantities for the respondents to perform safe food handling practices. Supplies tools and materials are not readily available in adequate quantities for the respondents to perform safe food handling practices. Equipment items needed to prepare food safely are readily available and accessible 
although there is need to add more. Majority of respondents were not being provided with quality supplies that make it easy to follow safe food handling practices. As a result adequate tools and equipment were available to prepare food safely.

Findings established that highly perishable and non-perishable foods are not stored together. Refrigerators are not over filled in such a way that there is limited circulation of air although there are separate refrigerators for storage of cooked foods and raw foods in the food production area. In addition, refrigerators have fixed thermometer reading, working services and equipment cleaned frequently, there are no incidents of food contamination or food poisoning, regular food-handling medical check-ups, fumigation done, no norms practiced by all food handler's brigade, never attended any in-service training, regular use of menu and procedures for food production, adequate recording of food items in the kitchen, temperature measurements and records of all food are taken during service, standardized and institutionalized food handling practices across the institution, measures are put in place to prevent food contamination and poisoning. Findings also established some compromises with safe practices when handling food and the need to provide the necessary security, although staff use the easiest, quickest, and cheapest way, which might lead to poor quality of food safety when preparing food.

Table 2: Food Handling Practices

\begin{tabular}{|c|c|c|c|c|c|}
\hline \multirow[t]{2}{*}{ Food Handling Practices } & \multicolumn{5}{|c|}{ Respondents Number \& Percent } \\
\hline & $\begin{array}{l}\text { Strongly } \\
\text { Disagree }\end{array}$ & Disagree & Neutral & Agree & $\begin{array}{l}\text { Strongly } \\
\text { Agree }\end{array}$ \\
\hline $\begin{array}{l}\text { Use of food gloves when preparing food } \\
\text { items }\end{array}$ & $\begin{array}{c}34 \\
(36.6 \%)\end{array}$ & $\begin{array}{c}57 \\
(61.3 \%)\end{array}$ & - & - & - \\
\hline $\begin{array}{l}\text { Use of detergent water when cleaning } \\
\text { vegetables }\end{array}$ & $\begin{array}{c}9 \\
(9.7 \%)\end{array}$ & $\begin{array}{c}82 \\
(88.2 \%)\end{array}$ & - & - & - \\
\hline Freezing of Food Commodities & $\begin{array}{c}55 \\
(59.1 \%)\end{array}$ & $\begin{array}{c}37 \\
(39.8 \%)\end{array}$ & - & - & - \\
\hline $\begin{array}{l}\text { Availability of refrigerator for storage of } \\
\text { perishable foods }\end{array}$ & $\begin{array}{c}79 \\
(84.9 \%)\end{array}$ & $\begin{array}{c}13 \\
(14.0 \%)\end{array}$ & - & - & - \\
\hline $\begin{array}{l}\text { Highly perishable and non-perishable } \\
\text { foods stored together }\end{array}$ & $\begin{array}{c}17 \\
(18.3 \%)\end{array}$ & $\begin{array}{c}74 \\
(79.6 \%)\end{array}$ & - & - & - \\
\hline $\begin{array}{l}\text { Refrigerators are over filled in such a way } \\
\text { that it limits circulation of air }\end{array}$ & $\begin{array}{c}17 \\
(18.3 \%)\end{array}$ & $\begin{array}{c}74 \\
(79.6 \%)\end{array}$ & - & - & - \\
\hline $\begin{array}{l}\text { Provision for separate refrigerator for } \\
\text { storage of cooked foods and raw foods }\end{array}$ & $\begin{array}{c}66 \\
(71.0 \%)\end{array}$ & $\begin{array}{c}12 \\
(12.9 \%)\end{array}$ & - & - & \\
\hline $\begin{array}{l}\text { Does the refrigerator have a fixed } \\
\text { thermometer reading }\end{array}$ & $\begin{array}{c}64 \\
(68.8 \%)\end{array}$ & $\begin{array}{c}25 \\
(26.9 \%)\end{array}$ & - & - & - \\
\hline Any incidences of food poisoning & $\begin{array}{c}12 \\
(12.9 \%)\end{array}$ & $\begin{array}{c}77 \\
(82.8 \%)\end{array}$ & - & - & - \\
\hline Visits for food handling medical checkups & $\begin{array}{c}66 \\
(71.0 \%)\end{array}$ & $\begin{array}{c}23 \\
(24.7 \%)\end{array}$ & - & - & - \\
\hline Fumigation done & $\begin{array}{c}69 \\
(74.2 \%)\end{array}$ & $\begin{array}{c}20 \\
(21.5 \%)\end{array}$ & - & - & - \\
\hline
\end{tabular}


Presence of norms practiced by all staff

training

Uses menu and procedures for food production

Any records of food to be prepared

Any records kept for food temperature

Food handling practices are standardized and institutionalized in the institution

Any measures on prevention on food contamination

Adequate supplies tools and materials readily available for safe food handling practices

Equipment items needed to prepare food safely (hand washing sinks) are readily available and accessible

Staff provided with quality supplies that makes it easy to follow safe food handling practices

Adequacy of resources to prepare food safely

Adequacy of Facilities Quality in order to follow safe food handling practices

No Compromises with safe practices are made when handling food

Respondents sometimes asked to cut corners with food safety to save costs when preparing food $\begin{array}{cc}19 & 69 \\ (20.4 \%) & (74.2 \%)\end{array}$

$\begin{array}{cc}18 & 71 \\ (19.4 \%) & (76.3 \%) \\ 81 & 9 \\ (87.1 \%) & (9.7 \%) \\ & \\ 83 & 6 \\ (89.2 \%) & (6.5 \%) \\ 63 & 27 \\ (67.7 \%) & (29.0 \%) \\ 59 & 30 \\ (63.4 \%) & (32.3 \%)\end{array}$

69

21

$(74.2 \%)$

$(22.6 \%)$

11

16

$(11.8 \%)$

$(17.2 \%)$

42

14

8

$(45.2 \%) \quad(15.1 \%)$

$(8.6 \%)$

$\begin{array}{ccccc}14 & 31 & 38 & 3 & 6 \\ (15.1 \%) & (33.3 \%) & (40.9 \%) & (3.2 \%) & (6.5 \%)\end{array}$

$\begin{array}{ccccc}10 & 35 & 34 & 9 & 3 \\ (10.8 \%) & (37.6 \%) & (36.6 \%) & (9.7 \%) & (3.2 \%) \\ & & & & \\ 16 & 32 & 32 & 8 & 4 \\ (17.2 \%) & (34.4 \%) & (34.4 \%) & (8.6 \%) & (4.3 \%) \\ 12 & 25 & 26 & 15 & 14 \\ (12.9 \%) & (26.9 \%) & (28.0 \%) & (16.1 \%) & (15.1 \%) \\ 19 & 28 & 25 & 6 & 8 \\ (20.4 \%) & (30.1 \%) & (26.9 \%) & (6.5 \%) & (8.6 \%) \\ 8 & 17 & 25 & 12 & 31 \\ (8.6 \%) & (18.3 \%) & (26.9 \%) & (12.9 \%) & (33.3 \%)\end{array}$

From the results $41.1 \%$ of food handling practices can be explained by food safety. Food handling practices contribute significantly to food safety. The null hypothesis that stated that food handling practices do not have a statistically significant influence on food safety at the institution was rejected. Tools provided in the workplace ensure that food safety practices are observed and adhered to (added four key informants); the same help in making work easy and promoting safety in industry (two key informants); and one key informant was of the opinion that tools are used to minimize food wastage while three key informants opined that tools make work efficient. All the key informants noted that there have never been incidences of food contamination or food poisoning in the institution. This means there are low food poisoning incidences in the institution. A report by WHO (2015) on estimates of the global burden of food-borne diseases that comprehensive reported the impact of contaminated food on health and well-being of individuals estimated that each year as many as 600 million, or almost 1 in 10 people in the 
world, fall ill after consuming contaminated food out of which, 420000 people die. The report further cited 31 agents of food-borne diseases that include bacteria, viruses, parasites, toxins and chemicals. This report emphasizes the importance of ensuring zero incidences of food poisoning by ensuring stringiest adherence to hygienic food handling.

\section{Food Handling Safety}

Findings also established the view on food handling safety as demonstrated in Table 3. Majority of the respondents (39.3\%) noted that food handling safety was fair while another $26.2 \%$ responded that it was good. This implies that food handling safety in the catering is fairly good. Similarly, key informants noted numerous hindrances to safe handling practices. One key informant noted that lack of cooperation from some staff members and lack of water are factors in the work place that hinder implementation safe food handling practices. Three key informants cited inadequate proper equipment and low water supply as hindrances to safe food handling practices as well as poor waste disposal while four informants opined lack of established systems as a hindrance. In addition, five key informants suggested lack of proper tracking and two noted ignorance.

Table 3: Views on Food Handling Safety

\begin{tabular}{lc}
\hline Response & Respondents Number \& Percent \\
\hline Poor & $12(19.7)$ \\
Fair & $24(39.3)$ \\
Good & $16(26.2)$ \\
Very Good & $7(11.5)$ \\
Excellent & $2(3.3)$ \\
\hline
\end{tabular}

\section{Implementation of HACCP Principles}

Third objective assessed the implementation of hazard analysis and critical control points principles and their effect on food safety at the National Youth Service Catering Units. Aspects highlighted included awareness on HACCP principles, continuing education courses on HACCP and food hygiene for food-handler, and implementation of HACCP principles. Majority of the respondents have no knowledge on HACCP or any other food safety standards since they had not been trained on the food safety standards as indicated in Figure 1. Respondents agreed that food-hygiene operating procedure had been documented although food safety practices as part of annual work performance evaluation are hardly followed. This further suggests that measures for safe food handling need strengthening as part of annual work performance evaluation. In terms of continuing education courses on HACCP and food hygiene, majority of the respondents did not think that there were continuing education courses on HACCP and food hygiene for food-handler being implemented (Figure 2). Implementation of HACCP principles is as explained in Table 4. Majority of respondents were of the opinion that food safety inspections by health inspectors help to ensure safe food handling practices are followed. HACCP principles can be explained by variance in food safety where the model applied was statistically significant to predict the outcome variable. Implementation of HACCP principles causes negative change in food safety. This was explained by the lack of education and lack of awareness of the policy. The null hypothesis that stated that implementation of HACCP principles do not have statistically significant effect on the food safety at the institution was rejected. 
Journal of Management and Economic Studies, vol.1, issue.2, pp.18-34

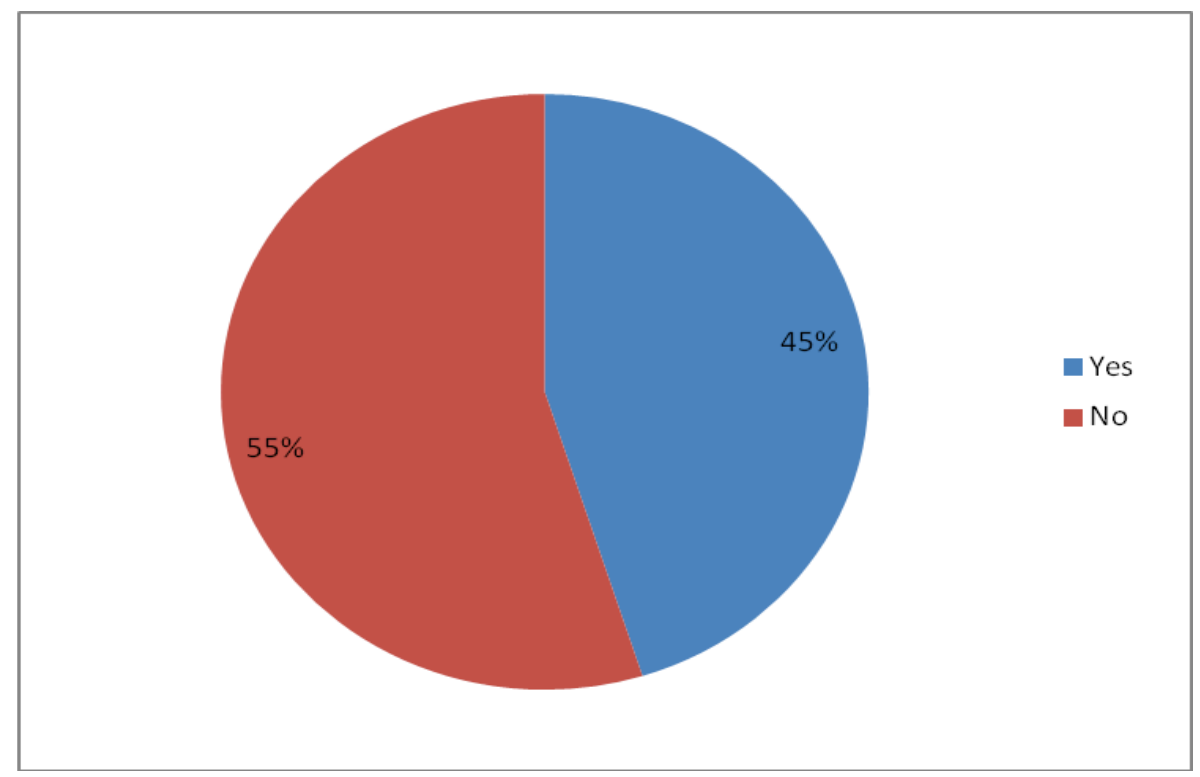

Figure 1: Knowledge of HACCP or Food Safety Standards

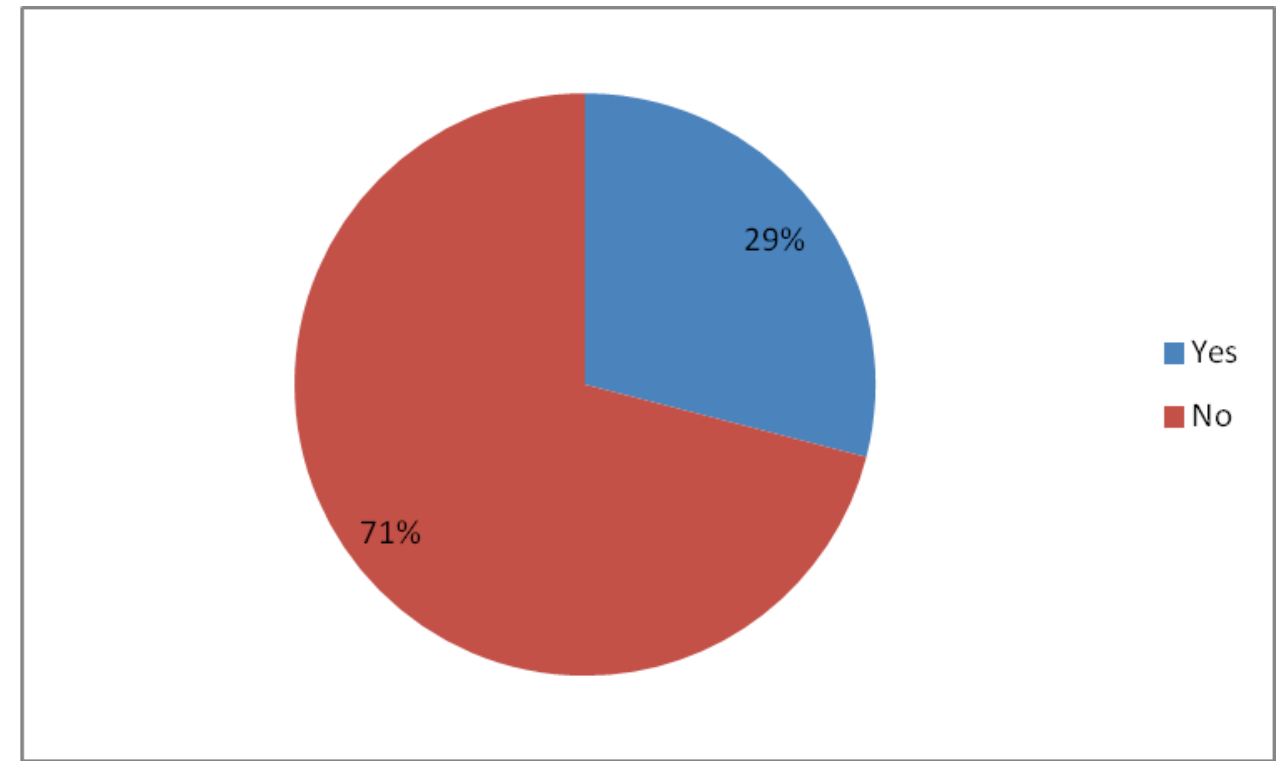

Figure 2: Continuing Education Courses on HACCP and Food Hygiene 
Table 4: Implementation of HACCP Principles

\begin{tabular}{lccccc}
\hline HACCP Implementation Practices & \multicolumn{5}{c}{ Respondents Number \& Percent } \\
\cline { 2 - 6 } & $\begin{array}{c}\text { Strongly } \\
\text { Agree }\end{array}$ & Agree & $\begin{array}{c}\text { Not } \\
\text { Sure }\end{array}$ & Disagree & $\begin{array}{c}\text { Strongly } \\
\text { Disagree }\end{array}$ \\
\hline $\begin{array}{l}\text { Food safety inspections by health } \\
\text { inspectors ensure Adherence to safe food }\end{array}$ & 19 & 28 & 25 & 6 & 8 \\
handling practices & $(20.4 \%)$ & $(30.1 \%)$ & $(26.9 \%)$ & $(6.5 \%)$ & $(8.6 \%)$ \\
$\begin{array}{l}\text { Employees are rewarded for following } \\
\text { safe food handling practices }\end{array}$ & 9 & 24 & 24 & 14 & 19 \\
$\begin{array}{l}\text { Adherence to food safety practices part of } \\
\text { annual work performance evaluation }\end{array}$ & $(8.6 \%)$ & $(25.8 \%)$ & $(25.8 \%)$ & $(15.1 \%)$ & $(20.4 \%)$ \\
$\begin{array}{l}\text { Any documentation of food hygiene } \\
\text { handling procedures }\end{array}$ & Yes & 23 & 23 & 11 & 16 \\
& No & $(58.1 \%)$ & & & \\
& & 25 & & & \\
\hline
\end{tabular}

\section{Conclusion}

- Institution provides written and well regarded food safety policies and procedures that guide the staff although the management need to offer adequate and timely information about current food safety rules and regulations. Fundamental information for handling food safely is not readily available to the staff. There is need to provide enough staff and adequate training in order to improve food safety practices.

- There is teamwork involving new and old employees as a measure of enhancing food safety. There is lack of good cooperation among departments to ensure that consumers receive safely prepared food. Overall, the staff views indicated that food safety policies and procedures help to ensure that safe food handling practices are followed.

- Staff should be encouraged at all times to use food gloves when preparing food items as well as detergents and water when cleaning vegetables. Equipments and tools for food preparation and production must be used for the intended purpose of safe food handling practices in addition to observing good hygiene standards.

- Continuous professional training and education courses on HACCP and food hygiene for food-handlers are important for the catering staff. This will provide the staff with adequate knowledge and skills on food handling and production practices.

\section{Recommendations}

- Compliance and adherence to HACCP principles and practices helps in preventing food poisoning. Management should also make the staffs to be more aware of HACCP and other safety standards, and should reward employees for following safe food handling practices.

- Management should encourage partnership and collaboration between different departments in order to enhance safe food production. Staff should be encouraged to use gloves as a measure of safe food production, and should use detergent water when cleaning vegetables and fruits.

- Institution should also increase the supplies of tools and materials in adequate quantities in order to promote safe food handling practices. Food safety practices should also be made to be part of the annual work performance evaluation for the staffs. 


\section{REFERENCES}

Aagaard, S. E. (2016). Take care: Food risk management and gendered household roles among Chinese women.

Abowitz, D., \& Toole, T. (2010). Mixed method research: Fundamental issues of design,validity and reliability in construction research.". J. Constr. Eng. Manage.,10.1061/(ASCE)CO.1943 7862.0000026, pp 108-116.

Al Busaidi, M. A., \& Jukes, D. J. (2015). Assessment of Food Control Systems in the Sultanate of Oman. Food Control 51(0), 59-69.

Al Yousuf, M., Taylor, E., \& Taylor, J. (2015). Developing a Government Strategy to Meet International Standards of Food Safety Across the Hospitality Industry. WorldwideHospitality and Tourism Themes, 7(1), 4-16.

American National Standards Institute. (2016). ISO 22000: Food safety management systems Requirements for any organization in the food chain. New York, USA.

Booty, F. (2009). Facilities Management Handbook. Routledge.

CDC. (2015). Preventing Future Outbreaks. Atlanta GA, USA.

Clayton, D., \& Griffith, C. J. (2008). efficiency of an extended theory Of planned behaviuor model for predicting cateres, hand hygenic practises. Internation journal ofenvironmental health,vol 18, PP 83-98.

Cochran, W. G. (2007). Sampling techniques. . John Wiley \& Sons.

Creswell, J. W., \& Plano Clark, V. L. (2011). Designing and Conducting Mixed Methods Research (2nd ed.). Thousand Oaks, CA: Sage Publications, Inc.

Dawso Van Druff, C. A. (2012). Implementation of school districts' food safety plans and perceptions of support for food safety and training in child nutrition programs in one USDA region. Des Moines.

Disease Outbreak News. (2017). Cholera, Kenya. Nairobi: World Health Organization.

FAO. (2016). Consumers and food safety: A food industry perspective. Food, nutrition and agriculture.

Foskett, D., \& Ceserani, V. (2007). The Theory of Catering 11th edition Abingdon. Hodder Arnold.

Fowler, F. J. (2013). Survey research methods. Sage publications.

Hampshire County Council. (2010). Food Safety Policy. Winchester, UK.

Huuhtanen, S., \& Laukkanen, A. (2006). A guide to sanitation and hygiene for those working in developing countries. Tampere: University of Applied .

Jabbar, M. A., \& Grace, D. (2012). Regulations for Safety of Animal Source Foods in Selected SubSaharan African Countries: Current Status and Their Implications. Nairobi, Kenya: International Livestock Research Institute.

Kothari, C. R. (2004). Research methodology: Methods and techniques. New Age International.

Lee, H. Y., Chik, W. N., Baka, F. A., Saari, N., \& Mahyudin, N. A. (2012). Sanitation Practices Among Food Handlers in a Military Food Service Institution, Malaysia. Food and Nutrition Sciences , 3 (11), 1561-1566. 
Mugenda, O. M., \& Mugenda. (2012). Research methods: Quantitative and qualitative approaches. African Centre for Technology Studies.

Mutavi, L. (2017). Cholera Fears as 59 Police Officers Taken Ill . Nairobi, Kenya.

Nguz, K. (2007). Assessing Food Safety System in Sub-Saharan Countries: An Overview of Key Issues. Science Direct Journal 18 (2), 131-134.

Oklahoma State University. (2016). Research Design in Occupation Education: Relliability and Validity. Oklahoma, USA.

Olielo, T. K., \& Rombo, G. O. (2009). The Availability of Processed Fruit Products and their Contents of Vitamins A and C in Nairobi, Kenya. African Journal of Food, Agriculture, Nutrition and Development, 9(1), 565-579.

Powell, D. A., Jacob, C. J., \& Chapman, B. J. (2011). Enhancing Food Safety Culture to Reduce Rates of Foodborne Illness. Food Control, 22(6), 817-822.

Sharif, L., \& Al-Malki, T. (2010). Knowledge, Attitude and Practice of Taif University Students on Food Poisoning. Food Control, 21(1), 55-60.

Shravani, S. (2012). Food Allergens and Food Safety: A Global Perspective with Respect to Codex Alimentarius. Journal of Food Science and Engineering, 2(8), 411-412.

Silver, C., \& Lewins, A. (2014). Using software in qualitative research: A step-by-step guide. Sage publications.

Standard Newspaper. (May 19, 2015). http://www.standardmedia.co.ke/article/2000162784/25students rushed-to-hospital-over-cholera-scare-in-nakuru-where-the-disease-has-killed-15people. Nairobi: standardmedia.co.ke.

Tansey, G., \& Worsley, A. (2014). The food system.Routledge. London: Pennine Pens.

Tavakol, M., \& Dennick, R. (2011). Making sense of Cronbach's Alpha. International Journal of Medical Education, 2, 53-54.

Taylor, J. (2011). An exploration of food safety culture in a multi-cultural environment: next steps?. Worldwide Hospitality and Tourism Themes, 3(5), pp 455.

Todd, E. C., Michaels, B. S., Greig, J. D., Smith, D. L., Holah, J., \& Bartleson, C. A. (2010). Outbreaks where food workers have been implicated in the spread of foodborne disease: Part 7: Barriers to reduce contamination of food by workers. J. Food Prot 73, 1552-1565.

Turner III, D. W. (2010). Qualitative Interview Design: A Practical Guide for Novice Investigators. The Qualitative Report, 15(3), 754-755.

University of Mississippi. (2017). Food Safety Standard Operating Procedures (SOPs). Oxford, USA: Institute of Child Nutrition.

Wagacha, J. M., \& Muthomi, J. W. (2008). Mycotoxin Problem in Africa: Current Status, Implications to Food Safety and Health and Possible Management Strategies. International Journal of Food Microbiology, 124(1), 1-12.

Walker, E., Pritchard, C., \& Forsythe, S. (2003). Hazard Analysis Critical Control Point and Prerequisite Programme Implementation in Small and Medium Size Food Businesses. Food Control, 14 (3), 169-174. 
Weiland, U. (2012). Teachings on environmental impact assessments in geography reflecting demands of the working practice: A German case study. Journal of Environmental Assessment Policy and Management, 14(03), 1250019.

WHO. (2007). Quality Assurance of Pharmaceuticals: A Compendium of Guidelines and Related Materials. Good Manufacturing Practices and Inspection 2(4), 12-15.

WHO. (2010). Hygiene related diseases Retrieved December 08 2010, from www.who.int/.

WHO. (2015). Estimates of the Global Burden of Foodborne Diseases. Geneva: World Health Organization.

Wilcock, A., Pun, M., Khanona, J., \& Aung, M. (2004). Consumer Attitudes, Knowledge and Behaviour: A Review of Food Safety Issues. Trends in Food Science \& Technology, 15(2), 56-66.

William, W. (2009). Research methods in education. Pearson Education India.

Yiannas. (2008). Food safety culture: Creating a behavior-based food safety management system. New York: Springer-Verlag, LLC.

Yiannas. (2009). Food Safety Culture. New York: Springer-Verlag. 